\title{
THE EFFECT OF PRINCIPALS' VISIONARY LEADERSHIP STYLE AND TEACHERS' WORK MOTIVATION ON THE ACCOUNTING TEACHERS' READINESS IN FACING CURICULLUM CHANGES WITH THE ORGANIZATIONAL CULTURE AS MODERATING VARIABLE
}

\author{
PENGARUH GAYA KEPEMIMPINAN VISIONER KEPALA SEKOLAH DAN \\ MOTIVASI KERJA GURU TERHADAP KESIAPAN GURU AKUNTANSI \\ MENGHADAPI PERUBAHAN KURIKULUM DENGAN BUDAYA ORGANISASI \\ SEBAGAI VARIABEL MODERASI
}

\author{
Oleh: \\ Marsha Tabarruj Albir Nurut \\ Prodi Pendidikan Akuntansi Universitas Negeri Yogyakarta \\ chacatabarruj@gmail.com
}

Mimin Nur Aisyah

Staf Pengajar Jurusan Pendidikan Akuntansi Universitas Negeri Yogyakarta mimin_nuraisyah@uny.ac.id

\begin{abstract}
It is a causal comparative research aimed to know : (1) The effect of Principals Visionary Leadership Style on the Teachers Readiness in facing Curriculum Change; (2) The effect of Teachers Work Motivation on the Teachers Readiness in facing Curriculum Change; (3) The effect of Principals Visionary Leadership Style on the Teachers Readiness in Facing Curriculum Change with the Organizational Culture as moderating variable; (4) The effect of Teacher Work Motivation on the Teachers Readiness in Facing Curriculum Change with the Organizational Culture as moderating variable. The research population was Accounting Teachers in three private Vocational High Schools (SMK) in Magelang. Data gathering was conducted through questionnaire distribution using census method. The classical assumption test covered linearity test, multicollinearity test and heterokesdasticity test. Data analysis technique used Simple Linear Regression and Moderated Regression Analysis (MRA). The research results showed that (1) Principals Visionary Leadership Style positively influenced Teachers Readiness in Facing Curriculum Change shown by value r(xly) of 0.742 , value r2(xly) of 0.550 , significant value was 0.000 ; (2) Teachers Work Motivation positively influenced Teachers Readiness in Facing Curriculum Change shown by $\mathrm{r}(\mathrm{x} 2 \mathrm{y})$ of 0.731 , value r2(x2y) of 0.535 , significant value was 0.000 ; (3) Organizational Culture could not moderate the influence of Principals Visionary Leadership Style on the Teachers Readiness in facing Curriculum Change shown by equation $\mathrm{Y}=-12.284+1.184 \mathrm{X} 1+1.123 \mathrm{Z}-0.012 \mathrm{X} 1 * \mathrm{Z}$ and the significant value of 0.653 ; and (4) Organizational Culture could not moderate the influence of Teachers Work Motivation on the Teachers Readiness in facing Curriculum Change shown by an equation $\mathrm{Y}=-36.197+1.559 \mathrm{X} 2+$ $1.937 \mathrm{Z}-0.028 \mathrm{X} 2 * \mathrm{Z}$ and significant value of 0.163 .
\end{abstract}

Keywords: Principals Visionary Leadership Style, Teachers Work Motivation, Teachers Readiness in Facing Curriculum Change, Organizational Culture

\section{Abstrak}

Penelitian ini merupakan penelitian kausal komparatif yang bertujuan untuk mengetahui: (1) pengaruh Gaya Kepemimpinan Visioner Kepala Sekolah terhadap Kesiapan Menghapai Perubahan Kurikulum; (2) pengaruh Motivasi Kerja Guru terhadap Kesiapan Menghadapi Perubahan 
Kurikulum; (3) Pengaruh Gaya Kepemimpinan Visioner Kepala Sekolah terhadap Kesiapan Menghadapi Perubahan Kurikulum dengan Budaya Organisasi sebagai variable moderasi; (4) Pengaruh Motivasi Kerja Guru terhadap Kesiapan Menghadapi Perubahan Kurikulum dengan Budaya Organisasi sebagai variable moderasi. Populasi penelitian ini adalah Guru Akuntansi di Tiga SMK Swasta Kota Magelang. Pengumpulan data dilakukan melalui penyebaran kuesioner, dengan menggunakan metode sensus. Uji asumsi klasik dalam penelitian ini meliputi uji linearitas, uji multikolinearitas, dan uji heteroskedastisitas. Teknik analisis data dalam penelitian ini menggunakan Regresi Linier Sederhana dan Moderated Regression Analysis (MRA). Hasil Penelitian menunjukkan bahwa (1) Gaya Kepemimpinan Visioner berpengaruh positif terhadap Kesiapan Menghadapi Perubahan Kurikulum ditunjukkan dengan nilai r(xly) sebesar 0,742, nilai $r^{2}(x 1 y)$ sebesar 0,550. Nilai signifikansi sebesar 0,000. (2) Motivasi Kerja berpengaruh positif terhadap Kesiapan Menghadapi Perubahan Kurikulum ditunjukkan dengan r(x2y) sebesar 0,731, nilai $r^{2}(x 2 y)$ sebesar 0,535. Nilai signifikansi 0,000. (3) Budaya Organisasi tidak dapat memoderasi pengaruh Gaya Kepemimpinan Visioner terhadap Kesiapan Menghadapi Perubahan Kurikulum ditunjukkan dengan persamaan $Y=-12,284+1,184 X_{1}+1,123 Z-0,012 X_{1} * Z$ dan nilai signifikansi sebesar 0,653. (4) Budaya Organisasi tidak dapat memoderasi pengaruh Motivasi Kerja terhadap Kesiapan Menghadapi Perubahan Kurikulum ditunjukkan dengan persamaan $Y=-36,197+1,559 X_{2}$ $+1,937 Z-0,028 X_{2} * Z$ dan nilai signifikansi sebesar 0,163.

Kata Kunci: Gaya Kepemimpinan Visioner Kepala Sekolah, Motivasi Kerja Guru, Kesiapan Guru Menghadapi Perubahan Kurikulum, Budaya Organisasi

\section{INTRODUCTION}

Curriculum is an essential thing in implementing education. In a simple way, curriculum can be defined as a lesson list that will be given to the students completely by giving attainment of mark in a particular time. A curriculum should be accommodate each student needs, which focus on the time and learning ability. So, curriculum is a complicated thing to be formulated. There are many factors in establishing a curriculum. Each curriculum has their own characteristic. Those characteristics show that each curriculum tries providing students who are ready with the era.

Curriculum is a guidance for the teachers in implementing teaching-learning process, so that curriculum has important role in the education itself. Indonesian curriculum is changing along with the newest government. There are some reasons and some studies for changing the curriculum. The changes are because the willingness of being better, developing, and improving the quality of national education. A good education is not only because of the curriculum. Nana Syaodih (E. Mulyasa, 2002:147) stated that it is no matter how good the curriculum but the result is in line with what have done by the teachers and the students in the classroom. It means that curriculum is not only the matter in gaining a success education but teachers' readiness to face the curriculum changes and how they implement it are also being a crucial roles.

Schools, as weapon in implementing a curriculum, are required to comprehend and implement it optimally and seriously, since the quality of educational process depends on it. However, in the real situation, there are many technical problems appear during the implementation of the newest curriculum, so that the school has to work hard and spend amount of time only comprehend the content and the purposes of the newest curriculum. Teachers should adapt to the changes of the previous curriculum to the newest curriculum. The on-going changes of the curriculum required the teachers to have well-readiness. If the readiness of the schools and teachers are not good so it will be meaningless.

There are several schools which are ready to the changes. Some of them are setting back their curriculum to the previous 
because they are not ready yet for the curriculum 2013. Therefore, it is necessary to know why many teachers are not ready to implement the regulation of the newest curriculum. Based on an observation that conducted on 14 September 2015, it were found that there were many schools which were not ready for the newest curriculum so it was not implemented yet. Some of the teachers knew about the changes but they were not ready yet. SMK 17 Magelang was one of schools that implementing Curriculum 2013 but they reverted to the previous curriculum (KTSP). Teachers' readiness is the crucial factor that caused the new curriculum is hard to be implemented.

The external factor that influence someone performance is working environment. Working environment is the management system, organizational culture and the leader and the partner (Steer and Porter, 1979). Therefore, in achieving the educational purpose, all of the aspects such as principal, teachers, students, staff, and the society have a big role for the school enhancement. Teachers' resources have a firm relation with the principal quality who has a good leadership style so that can be affected to the school environment. In addition, teachers' motivation in improving their ability and cultural organizational that is ready for the change in the school will give significant effect.

A principal as a booster of every sources in his school, mainly teachers and staffs. All of the school activities should be covered and approved by the principal. A principal has a big responsibility to develop and achieve the school's purpose. For achieving those things, a principal needs good teachers, high-motivated students, qualified staffs, and a good society. A principal should lead the teachers and always provide a good climate and atmosphere to build a good relation with the teachers and staffs. With the principal's support, a trust will be built and will improve the teachers' performance.
Leadership style is a system of leader which is very special in influencing the subordinates. Each leader has specific attitude and habit in doing his/her role. Those attitude are gained from the experiences, education, and social relationship. In other word, principal's leadership style is really influential to the teachers' performance and maximize the teachers' knowledge for preparing their selves in facing the curriculum changes. According to Hersey dan Blanchard (1977), "the style of leaders is the consistent behavior patterns that they use when they are working with and through other people as perceived by those people", which means that the style of leadership is the consistent patterns of behaviour of the leaders that use when they work together and through other people.

The developments in the Organization at any time push every leader to have spesific characteristic. At the time of a process of leadership occurred, a leader need to applying a particular leadership style. The development of the theory of leadership has been widely interpreted by experts, among others: the charismatic leadership, miiteristik leadership, situational leadership, transformational leadership, operational leadership, and visionary. From all kind of leadership style, which is considered the most effective was visionary leadership style. Because the visionary leadership is considered one of the most effective in facing the challenges of the changes that occur in the era of globalization that continues to change.

Seth Kahan, 2002 explained that the visionary leadership involves the willingness, ability, skill to offer success and glory in the future. A visionary leader able to anticipate any incidents that may arise, manage the future and encourage others to do the best. It means, visionary leaders able to see every challenges and opportunities to encourage organisations to achieve a purpose. The leadership that has 
vision (visionary leadership) that is leadership whose focus on a future challenges and encourage Member of organizations to improve their spirit.

It can be seen in SMK 17 Magelang, principal's role is important for the school improvement, teachers' performance, relation between co-workers and teachers' achievement. If the principal are not able to grow teachers' spirit by Guiding and supervising the teachers then teachers will not have spirit to improve their ability and performance. Through the observation that conducted by the researcher, the principal of SMK 17 Magelang were less in doing supervision and supporting the teachers to improve their performance. It was shown by the principal who never came to the class for evaluating and observing the teachers' performance. If the principal did not do the observation to the teachers it will make the teachers never have a willing to improve their ability and performance because there is no maximal supervision and evaluation by the principal. Whereas, the leadership style gives significant effect to the teachers and school improvement. If the principal is not active in expressing opinions and share information, then there is no new ideas in discussion received by the teacher, there is no challenge to improve their spirit, in order to improve teacher confidence to take the risk to achieve the purpose of the school, and prepare for future changes.

Internal factors, that influence someone performance, are educational background, intelligence, talent, interest, and motivation. Motivation is the important factor for the teachers for facing the changes. Motivation is an internal condition that enable the teachers appearing some actions that related to the learning process. According to Ames (1984), there are three kind of teachers' motivation. Those are first, motivation that related to the evaluation to his/her ability. Teachers try to improve their knowledge and their ability by presenting the best performance. Second, motivation that oriented to the finishing the duty perfectly. Third, motivation that related to the responsibility. Teachers' low motivation become the main factor of readiness to face the curriculum because high-motivated and high-committed teachers will have a good spirit on doing innovation and transformation of the curriculum and improving their competency.

The success of alteration of a curriculum in a school is related to the teachers and principal because they are the keys of every components and dimension in a school. Teachers' readiness is a main element of the implementation the new curriculum in their school. The effort to improve teachers' readiness is by doing motivation, working without motivation seems boring for the teachers. Motivation is a gift and the machine that can create eagerness for creating a good cooperation which is integrated to the effort in order to achieve the satisfaction. Motivation is a human potential power that can be developed by their own selves or by the other, including the principal. In psychology, motivation means everything that can be a support of any action. (M. Alisuf Sabri, 1996:85). It means that with motivation, teachers will do their best by giving their entire performance, mind, ability to achieve the education purpose.

Teacher is being an educator because there is motivation to educate. With the motivation, teachers can form a high spirit. Teachers' ability that based on motivation will carry out a strong character so that can be driven to the specific aim. Therefore, the success in doing their duty because of motivation have accomplish teachers need. Every activity that had been done by the teachers is appropriate with their necessity.

Motivated teachers will improve their performance because their satisfaction and need are gained and it caused the achievement of the purpose of education optimally and effectively. Therefore, in building achievement and work quality of 
the teachers should be given a motivation as a support to gain the purpose, as an effort to protect relation and eliminate the gap between the teachers, up grading teachers' prosperity, and adapt to any condition. As a person who is always growing to improve school quality, so applying government policy, namely implementing the newest curriculum, is necessary because we need to follow the modernization.

Teachers' motivation should be improved to carry the teacher to the good level of performance and accept the newest curriculum. Based on the result of observation that was done by the researcher, it is shown that teachers' motivation was still in low level. It is provided by there were many teachers who didn't finish his duty because, in the teaching period, teacher left the classroom and let the students did the assignment without any guidance, it also shown by there were many teacher who came late and caused the students did nothing inside the classroom. Moreover, there were many teacher who only made the Lesson Plan (RPP) when they will be supervised or in the time of accreditation scoring.

The principals leadership style is related to the way of guiding, driving, affecting, and directing the teachers to the specific aim. To improve the principals' leadership style and teachers' motivation, it is needed to have a good organizational culture. Organizational culture is a working culture because it can't be divided from the human resources. Organizational Culture is difficult to be defined firmly and to be measured, but it can be felt by the human resources inside the organization. An organization is formed from some individual who has a different character, skill, education, and preparing the teachers to face every change inside the school.

A strong culture inside the organization will give a support to the members to do as the expectation of the organization. With the loyalty to the organization regulation, so it is hoped it will optimize the performance and the productivity to achieve the school purpose. The organizational culture is rising because of teachers' experience. The strength of the culture depends on how the teachers implementing the values of the culture itself. A strong culture will give a significant effect to the relation between principle and teachers. Therefore, the teachers will feel comfort to the school environment and improve their performance. An organizational culture can be used as the motivator for teachers in doing their work.

Organizational culture is not the same with a regulation or rules. Rules is made to be obeyed and will give a punishment for whoever breaks the rules. Meanwhile, organizational culture can't be forced to anyone. If someone breaks the organizational culture, there is no strict punishment but his partners will give a bad mark to him/her. Based on the observation that was done by the researcher, there were some problems occurred in the field of organizational culture such as there was less of cooperation between teachers and the staff because the decision based on the senior teachers, so that the new teacher just following the decision without gave any suggestion, there was less of the response to the innovation. For example, the teachers seemed ignoring the newest curriculum and the principal's regulation, there was no punishment for anyone who breaks the school regulation so the teacher ignored it.

The importance of developing organizational culture inside the school is mainly about the effort of achieving the education aim in the school and improving school's performance. According to Stephan Stolp (1994, in ERIC Digest), school culture is related to the improvement of motivation, students achievements, the working satisfaction and the teachers' productivity. Based on the expert, it can be concluded that organizational culture have an important role in gaining the aim of the school's 
purposes and motivating teachers to improve their ability and performance to implement the newest curriculum in order to up grading the quality of their school.

Based on the discussion above, it can be seen that teachers' readiness to face curriculum changes is important. It will not be happened without a great support from the principal who has a good leadership style, high motivation of the teachers and the organizational culture that support each other to accept the good change in the school. The researcher tried to analyse the effect of factors of work motivation and the principals' visionary leadership style that affected to teachers' the readiness to face the on-going curriculum changes, in order to make the other schools are ready to implement the same curriculum with the other. Therefore, the researcher did a research about the effect of factors of work motivation and principals' visionary leadership style to the teachers' readiness to face curriculum changes in SMK 17 Magelang, SMK Bhakti Karya, and SMK Muhammadiyah Magelang.

\section{RESEARCH METHOD Research Design}

This research was descriptive research with quantitative approach because the result of measurement would be more accurate. The data in the form of number can be processed by statistical method. According to Whintney (1960), descriptive method is a search of fact with a correct interpretation. According to Sugiyono (2012:13), quantitative data is a characteristic from a variable that the values are stated in the form of numerical.

\section{Location and Time of The Research}

This research was conducted in SMK 17 Magelang, SMK Bhakti Karya, and SMK Muhammadiyah Magelang. This research process included writing proposals, implementation research, and reporting that were conducted from February to June 2016.

\section{Population}

Population is the whole research population (Suharsimi Arikunto, 2002:108). The population of the research were accounting teachers of three private vocational high schools in Magelang City.

\section{Procedure}

The method that used in this research was census, as the way of collecting data when all elements of the population investigated. The data obtained were the result of processing the Census as the actual data (Zulnaidi, 2007:13). The respondents of this research were 19 teachers of SMK 17 Magelang, 15 teachers of SMK Bhakti Karya, and 21 teachers of SMK Muhammadiyah Magelang.

\section{Instrument Research}

This research used a questionnaire research instruments. the questionnaire contained statements regarding the list of independent variables (Work Motivation and Visionary Leadership Style), and moderating variables (Organizational Culture) using a Likert Scale. Likert Scale is a method to measure attitudes to agree or disagree from the subject, object or specific events (Indriantoro and Supomo, 2002:104).

\section{Data Analysis Teachniques}

Data analysis is a process that simplify the data to the easy form to be understand and interpreted. By using quantitative method, it is expected to get the accurate result of measurement about the response that given by the respondents so the numerical data can be processed by statistical method.

a. Validity

Validity test is to measure the questionnaire whether it is valid or not. A questionnaire is valid if it reveals the 
matter to be measured by the questionnaire (Ghozali, 2006).

The method to do a validity test is by doing correlation between the score of each question and the total construct score or variable. If a measuring instrument has a significant correlation between the score of item and the total score then score is valid (Ghozali 2006).

The formula of validity test is as follows:

$r_{\mathrm{ky}}=\frac{\mathrm{N} \Sigma \mathrm{XY}-(\Sigma \mathrm{X})(\Sigma \mathrm{Y})}{\sqrt{\left\{\mathrm{N} \Sigma \mathrm{X} 2-(\Sigma \mathrm{X})^{2}\right\}\left[\mathrm{N} \Sigma \mathrm{Y} 2-(\Sigma Y)^{2}\right\}}}$

(Suharsimi, 2006)

b. Reliability

Reliability test is an instrument to measure the questionnaire that constitute variable indicator or construct. A questionnaire is reliable if the answer to the question is consistence and stable all the time (Ghozali, 2016). Variable or construct is categorized reliable if the cronbach alpha > 0.06 (Ghozali, 2006).

the formula of reliability test is as follows:

$r_{i}=\left[\frac{k}{k-1}\right]\left[1-\frac{\Sigma a^{2} b}{a^{2} t}\right]$

(Suharsimi, 2006)

\section{c. Multicollinearity Test}

This measurement is to measure is there any independent variable in the regression model or not. It there is found any multicollinearity, then, variable regression coefficient is not uncertain and the error become limitless (Ghozali, 2016). Tolerance of measuring the variability of selected independent variable can be explained by other the independent variable. So, the score of low tolerance is same with the score of high VIF (VIF=1/tolerance) and show the high collinearity. The score of cut-off that is commonly used is tolerance score 0,10 or same with VIF score above 10 (Ghozali,2009).

$$
\mathrm{VIF}=\frac{1}{\text { Tolerance Vaiue }}
$$

(Santoso, 2000)

\section{d. Heteroscedaticity Test}

This testing is to test is there any inequality variance from the residue from an observation to another in regression model or not. A good regression model is that homoscedasticity one, which is variance from the residual of an observation to the other is constant (Ghozali, 2009). The testing of glejser test to the regression model that is not heteroscedaticity, should be qualified some criterion. Those are:

1) If it has a significant variable so it indicates that there has been a heteroscedaticity.

2) If it has not a significant variable so it indicates that there has been a heteroscedaticity.

e. Linearity Test

Linearity test is used for finding whether independent variable and dependant variable on the research has linear corelation by the increasing of independant score following by the incresing of dependant variable score (Imam Ghozali, 2011). Criteria applied on the linearity is $\mathrm{F}$ with mathematical formula:

$$
\mathrm{F}_{\text {reg }}=\frac{R k_{r \theta g}}{R k_{\text {res }}}
$$

f. Hypothesis Test

(Sutrisno Hadi, 2004)

\section{1) Simple Linier Regression}

Simple regression can be used to predict scores on independent from the scores on a dependent variable (Santoso, 2000). In this Research, a simple linier regression analysis was used to test hypothesis $1(\mathrm{H} 1)$ there is positif effect and significant between principals visionary 
leadership style on the teacher readiness in facing curriculum changes and Hypothesis $2(\mathrm{H} 2)$ there is positif effect and significant between work motivation on the the teacher readiness in facing curriculum changes. Simple regression analysis test to prove the hypothesis, with the steps:

$$
\mathrm{Y}=\mathrm{a}+\mathrm{bX}
$$

(Sugiyono, 2012)

2) Moderated Regression Analysis

To test the hypothesis those are Work Motivation, Principals' Visionary Leadership Style, interaction between Work Motivation and Organizational Culture and interaction between Principals' Visionary Leadership Style and the Organizational Culture on the Teachers Readiness in facing Curriculum Changes by regression equation through interaction test or often called as Moderated Regression Analysis (MRA). MRA is a special application of multiple linear regression in an equation of its regression that contains some elements of interaction (multiple independent variable) as follows (Ghozali, 2006).

$\mathrm{Y}=\alpha+\beta . \mathrm{x} 1+\mathrm{e}$

$\mathrm{Y}=\alpha+\beta . \mathrm{x} 2+\mathrm{e}$

$\mathrm{Y}=\alpha+\beta 1 . \mathrm{x} 1+\beta 2 . \mathrm{z}+\mathrm{e}$

$\mathrm{Y}=\alpha+\beta . \mathrm{x} 1+\beta 2 . \mathrm{z}+\beta 3 . \mathrm{x} 1 * \mathrm{z}+\mathrm{e}(\mathrm{H} 3)$

$\mathrm{Y}=\alpha+\beta 1 . \mathrm{x} 2+\beta 2 . \mathrm{z}+\mathrm{e}$

$\mathrm{Y}=\alpha+\beta . \mathrm{x} 2+\beta 2 . \mathrm{z}+\beta 3 . \mathrm{x} 2 * \mathrm{z}+\mathrm{e}(\mathrm{H} 4)$

(Sugiyono, 2012)

\section{RESULTS AND DISCUSSIONS}

\section{Research Result}

a. Description of Specific Data

1) Teachers Readiness in Facing Curriculum

Based on processed teachers' readiness in facing curriculum change data with the number of respondents 51 teachers, it was retrieved values as follows: mean 57.451, mode 58.00 median 58.000 , standard of deviation, 5.10025, maximum 66.00, minimum 48.00 .

After $\mathrm{Mi}$ and SDi were recognized and then were categorized into three categories i.e. low, medium, high. More calculations can be seen on the attachment pages.

Table 3. Inclination

Frequency Distribution of the Readiness in Facing Curriculum Changes variable.

\begin{tabular}{|c|c|c|c|}
\hline Interval & $\mathbf{F}$ & $\begin{array}{c}\text { Percentage } \\
(\boldsymbol{\%})\end{array}$ & categories \\
\hline$<34$ & 0 & $0.00 \%$ & Low \\
\hline 34 s/d 51 & 10 & $19.61 \%$ & Medium \\
\hline$>51$ & 41 & $80.39 \%$ & High \\
\hline Total & 51 & $100 \%$ & \\
\hline
\end{tabular}

Resource: processed primary data 2016

2) Visionary Leadership Style

Based on the processed data of Visionary Leadership Style by the number of respondents 51 accounting teacher, then the retrieved value is as follows: 44.1176 mean, mode 43.00, standard deviation 3.84524, maximum 52, and minimum 38 .

After $\mathrm{Mi}$ and $\mathrm{SDi}$ were recognized, then they categorized into three categories i.e. low, medium, high. More calculations can be seen on the attachment page.

Table 5. Inclination Frequency

Distribution of Visionary

Leadership Style Variable

\begin{tabular}{|c|c|c|c|}
\hline Interval & $\mathbf{F}$ & $\begin{array}{c}\text { Percentage } \\
(\boldsymbol{\%})\end{array}$ & Categories \\
\hline$<26$ & 0 & $0.00 \%$ & Low \\
\hline 26 to 39 & 7 & $13.73 \%$ & Medium \\
\hline$>39$ & 44 & $86.27 \%$ & High \\
\hline
\end{tabular}


Total

41

$100 \%$

Resource: processed primary data 2016

3) Work Motivation

Based on Work Motivation data that were processed by the number of respondents 51 of accounting teachers, then it was retrieved value as follows: mean was 47.0392, mode was 45.00, standard deviation was 4.98783, maximum 56, and minimum 36.

After the $\mathrm{Mi}$ and $\mathrm{SDi}$ were recognized, they were categorized into three categories i.e. low, medium, high. More calculations can be seen on the attachment page.

Table 7. Inclination Frequency

Distribution of Work

Motivation Variable

\begin{tabular}{|c|c|c|c|}
\hline Interval & $\mathbf{F}$ & $\begin{array}{c}\text { Percentage } \\
(\mathbf{\%})\end{array}$ & Categories \\
\hline$<28$ & 0 & $0.00 \%$ & Low \\
\hline 28 s/d 42 & 9 & $17.65 \%$ & Medium \\
\hline$>42$ & 42 & $82.35 \%$ & High \\
\hline Total & $\mathbf{5 1}$ & $\mathbf{1 0 0 \%}$ & \\
\hline
\end{tabular}

Resource: processed primary research data 2016

4) Organizational Culture

Based on the processed organizational culture data with the number of respondents 51 accounting teachers, then the retrieved value was as follows: mean was 33.6275, mode was 39.00, standard deviation was 3.91898, maximum was 40 , and minimum was 27.

After Mi and SDi are recognized, they were categorized into three categories i.e., weak, medium, strong. More calculations can be seen on the attachment page.
Table 9. Inclination

Frequency

Distribution of Organizational

Culture Variable

\begin{tabular}{|c|c|c|c|}
\hline Interval & $\mathbf{F}$ & $\begin{array}{c}\text { Percentage } \\
(\mathbf{\%})\end{array}$ & Categories \\
\hline$<20$ & 0 & $0.00 \%$ & Weak \\
\hline 20 to 30 & 13 & $25.49 \%$ & Medium \\
\hline$>30$ & 38 & $74.51 \%$ & Strong \\
\hline Total & $\mathbf{5 1}$ & $\mathbf{1 0 0 \%}$ & \\
\hline
\end{tabular}

Resources: processed primary data 2016

b. Data analysis

1) Linearity Test

Table 10. Linearity Test Result

\begin{tabular}{|c|c|c|}
\hline Correlation & Sig & Criteria \\
\hline $\mathrm{X}_{1}-\mathrm{Y}$ & 0.487 & Linear \\
\hline $\mathrm{X}_{2}-\mathrm{Y}$ & 0.064 & Linear \\
\hline
\end{tabular}

Resource: processed primary data 2016

Based on the table above, the significant value of Visionary Leadership Style on the Teachers Readiness in facing curriculum change was 0.487 and significance value of Working Motivation on the Teachers Readiness in facing Curriculum Changes was 0.064 . The significant value was greater than 0.05 , so it can be concluded that the influence of each independent variable towards the dependent variable are linear.

2) Multi co-linearity Test

Table 11. Multi Co-linearity Test Result

\begin{tabular}{|c|c|c|}
\hline \multirow{2}{*}{ Variabel } & \multicolumn{2}{|c|}{ Collinearity Statistics } \\
\cline { 2 - 3 } & Tolerance & VIF \\
\hline $\mathrm{X}_{1}$ & 0.492 & 2.034 \\
\hline $\mathrm{X}_{2}$ & 0.492 & 2.034 \\
\hline
\end{tabular}

Resource: processed primary data 2016

Table 11 shows that the value of the VIF (Variance Inflation Factor) Visionary Leadership Style variable and Work Motivation was 2.034. Overall, 
the value was less than 10 . Besides, the value of the Tolerance for Visionary Leadership Style variable and work Motivation was 0.492 and greater than $10 \%$. Thus, it could be concluded that in the regression model cannot be found the existence of a multi co-linearity among the independent variables.

3) Homoscedasticity Test

Test homoscedasticity aimed to test whether the regression model occurred inequality variance from residual between observations or not. To find out existence of homoscedasticity in the data, Glejser test was used. If the significance was larger than a predetermined significance level i.e. 5\%, then homoscedasticity was not occured.

Table 12. Homoscedasticity Test

\begin{tabular}{|l|l|l|}
\hline V & Sign & Description \\
\hline $\mathrm{X} 1$ & 0.435 & not occured \\
\hline $\mathrm{X} 2$ & 0.807 & not occured \\
\hline
\end{tabular}

From above data, it could be known that Visionary Leadership Style had the significance at 0.435 and Work Motivation had significance at 0.807 or greater than $5 \%(0.05)$, so that it could be summed up that homoscedasticity was not occuring.

c. Hyphothesis Test

1) H1: There was a significant and positive influence of Visionary Leadership Style on the Teachers Readiness in Facing Curriculum Changes.
Table 13. Results of The Simple Regression Analysis the First Hypothesis $\mathrm{H}_{1}$

\begin{tabular}{|l|c|}
\hline \multicolumn{1}{|c|}{ Variable } & $\mathbf{X}_{\mathbf{1}}-\mathbf{Y}$ \\
\hline $\mathrm{r}(\mathrm{xly})$ & 0.742 \\
\hline $\mathrm{r}^{2}(\mathrm{x} 1 \mathrm{y})$ & 0.550 \\
\hline Sig & 0.000 \\
\hline Konstanta & 14.049 \\
\hline Coefficient & 0.984 \\
\hline
\end{tabular}

*Independent Variable Visionary

Leadership Style

Resource: processed primary data 2016

2) H2: There was significant and positive influence of Working Motivation on the Teachers' Readiness in Facing Curriculum Changes.

Table 14. Summary of Simple Regression Analysis Result on $\mathrm{H}_{2}$

\begin{tabular}{|l|c|}
\hline \multicolumn{1}{|c|}{ Variable } & $\mathbf{X}_{\mathbf{2}}-\mathbf{Y}$ \\
\hline $\mathrm{r}(\mathrm{x} 2 \mathrm{y})$ & 0.731 \\
\hline $\mathrm{r}^{2}(\mathrm{x} 2 \mathrm{y})$ & 0.535 \\
\hline Sig & 0.000 \\
\hline Konstanta & 22.279 \\
\hline Coefficient & 0.748 \\
\hline
\end{tabular}

*Independent Variable Work Motivation Resource: processed primary data 2016

3) H3: Organizational Culture can moderate the influence of Visionary Leadership Style on the Teachers Readiness in Facing Curiculum Changes.

Table 15. Result of Moderated Regression Analysis $\mathrm{X}_{1}$ with $\mathrm{Z}$ towards $\mathrm{Y}$

\begin{tabular}{|l|l|}
\hline Equation 1 & $\mathrm{Y}=14.049+0.984 \mathrm{X}_{1}$ \\
\hline Equation 2 & $\mathrm{Y}=5.152+0.728 \mathrm{X}_{1}+$ \\
& $0.601 \mathrm{Z}$ \\
\hline Equation 3 & $\mathrm{Y}=-12.284+1.128 \mathrm{X}_{1}+$ \\
& $1.123 \mathrm{Z}-0.012 \mathrm{X}_{1} * \mathrm{Z}$ \\
\hline
\end{tabular}

Resource: processed primary data 2016 
Based on the analysis above, it can be concluded that the third hypothesis could not be supported which means that Organizational Culture did not moderate the influence of Principals Visionary Leadership Style against the Accounting Teacher Readiness in facing Curriculum Changes, thus the third hypothesis was rejected.

4) H4: Organizational Culture can moderate the influence of Working Motivation on the teacher readiness in facing curriculum changes.

Table 16. Result of Moderated Regression Analysis $\mathbf{X}_{2}$ with $\mathbf{Z}$ towards $\mathbf{Y}$

\begin{tabular}{|l|l|}
\hline Equation 1 & $\mathrm{Y}=22.279+0.748 \mathrm{X}_{2}$ \\
\hline Equation 2 & $\mathrm{Y}=9.493+0.565 \mathrm{X}_{2}+$ \\
& $0.636 \mathrm{Z}$ \\
\hline Equation 3 & $\begin{array}{l}\mathrm{Y}=-36.197+1.559 \mathrm{X}_{2}+ \\
1.937 \mathrm{Z}-0.028 \mathrm{X}_{2} * \mathrm{Z}\end{array}$ \\
\hline
\end{tabular}

Resource: processed primary data 2016

Based on the analysis above, it can be concluded that the fourth hypothesis cannot be supported which means that Organizational Culture does not moderate the influence of Working Motivation on the Accounting Teacher Readiness in Facing Curriculum Changes, thus the fourth hypothesis is rejected.

\section{Discussions}

a. The positive and significant effect Visionary leadership style on the Teachers Readiness in Facing Curriculum Changes

The results showed that there was a significant and positive effect of visionary leadership style against the readiness of Teachers in facing curriculum changes. Value of significance was smaller than the level of significance $(0.000<0.050)$. The first hypothesis ( $\mathrm{H} 1)$ mentioned that there is a significant and positive influence of visionary leadership style on the teachers readiness in facing curriculum changes, is accepted. This means that the higher the Visionary leadership style which belonged to the principal, then Accounting teachers' readiness in facing curriculum changes would also be increased.

The Research showed the highest score on visionary leadership style variable in the statement principals already make the vision and mission of the school together with the teachers, about what can be achieved in the future. The lowest score in the statement the principal was open minded to receive any complaints from teachers. In other words eventhough the principal has made mission and vision together with teachers, but the accounting teacher considered the principal was less open minded to receive any suggestion from teachers against the difficulties in the curriculum implementation. This means that the principal Visionary leadership style can encourage teachers to be able to confront and prepare to curriculum change in the future.

The results of this study is in accordance with the research conducted by Ni Ketut Suarni (2005). The results revealed that influential positive leadership style against the readiness of the implementation of the curriculum.

b. The positive and significant effect Work Motivation on the Teachers Readiness in Facing Curriculum Changes

Results showed that there was a significant and positive influence Work Motivation against the readiness in facing curriculum change. Value of significance was smaller than the level of significance $(0.000<0.050)$. it had a meaning that the motivation of working influence 
significantly to the readiness in facing curriculum changes. The second hypothesis $(\mathrm{H} 2)$ mentioned that there was a significant positive influence and working motivation against the readiness in facing curriculum changes, was successfully supported by data or it is accepted. The higher the work motivation level belonging to the accounting teacher, then the Readiness in Facing Curriculum Changes will be better.

The Research showed that the motivation of working encourages teachers to be obedient towards the principals given instruction, security assurance and serenity in the job was good. This is demonstrated the highest score on Work Motivation variable, while the lowest score is in the statement the accounting teacher feel challenged in the face of adversity. Although accounting teacher already follow the principals instruction, but the difficulty is looking for ways in overcoming hardship and it had an impact on their readiness in preparing curriculum development in the future.

The results of this study was in accordance with the research done by Nasrun and Martias (2015). This results show the positive effect of work Motivation on readiness to implement the curriculum.

c. Organizational culture can moderate the influence of Visionary leadership style against the Teacher in Facing Curriculum Changes

Results showed that organizational culture did not moderate the influence of visionary leadership style on the readiness in facing curriculum changes. The interactions between the Visionary Leadership Style and Organizational Culture yields the value of significance 0.653 which was greater than levels of significance 0.050 . Therefore, Organizational Culture variable proved to be unable to moderate the influence of
Principals Leadership Style on the Teacher Readiness in Facing Curriculum Changes. The results obtained in this study indicated that the Organizational Culture could not moderate the Principals Visionary Leadership Style on the Teacher Readiness in Facing Curriculum Changes.

This is evidenced by the low score in openess to ideas and opinions from teachers. Culture in schools encouraged accounting teachers to work in a coordinated effort, The high score in the statement "I was always encouraged to work in a coordinated model, but in fact lack of planning in the face of a change". The low score in the statements "all over the teachers and principals help planning ahead for the schools". It it possible that Organizational Culture is an environmental product that was agreed and interpreted together among the members of school. Organizational Culture sometimes in contrast with Visionary Leadership Style, especially if the implemented Organizational Culture is an old culture which often creates conflict to Visionary Leadership Style that gives information and description in the future.

The Organizational Culture in this study could not moderate the influence of Principals Visionary Leadership Style on the Accounting Teacher Readiness in facing curriculum changes. These results was in accordance with the studies done by Made Sudarma and Sutrisno (2012). This results show the organizational culture significantly cannot moderate the visionary leadership style in the face of change.

d. Organizational Culture can moderate the influence of Work Motivation on the Teachers Readiness in Facing Curriculum Changes

Results showed that Organizational Culture cannot moderate the influence of Working Motivation on the Teachers 
Readiness in Facing Curriculum Changes. Interaction between Working Motivation and Organization Culture that produced the value of significance 0.163 , this was greater than levels of significance i.e. 0.050 , so that the Organizational Culture variable was not proven to moderate the influence of Working Motivation on the Teachers Readiness in Facing Curriculum Changes.

Organizational Culture is an agreed product of environment and implemented by member organizations in the school environment. However, the Organizational Culture is sometimes contrary to the motivation of working, especially if the implemented Organizational Culture is the old culture that often conflicting Working Motivation. The result of the research showed accounting teachers had a high motivation to complete a task, but in fact the teachers were lacked of planning about what will be faced in the future. This is evidenced by the high score on the statement "accounting teacher completes a task on time", while the lowest score "all over the teachers and principals help planning ahead for the school".

Then the Organizational Culture in this study could not moderate the influence of Teachers Work Motivation on the Accounting Teachers Readiness in Facing Curriculum Changes. These results was in accordance with research done by Sholihul Fuad and Cecilia Sri Mindarti (2014) that shows the Organizational Culture could not moderate the motivation to work on teacher in Sub Winong of Pati.

\section{CONCLUSION AND SUGGESTIONS}

\section{Conclusion}

1. There is positive and significant effect of Principals Visionary Leadership Style of on the Teacher Readiness in
Facing Curriculum Changes at SMK 17 Magelang, SMK Bhakti Karya, and SMK Muhammadiyah Magelang. This is proved by the value of Significance $(0.000<0.050), \quad$ and regression coefficient X10.984.

2. There is positive and significant effect of Working Motivation on the Teacher Readiness in Facing Curriculum Change at SMK 17 Magelang, SMK Bhakti Karya, dan SMK Muhammadiyah Magelang. This is proved by the value of Significance $(0.000<0.050)$, and regression coefficient X2 0.748.

3. Organizational Culture can not serve as moderating variable in the relationship between Principals Visionary Leadership Styles and Work Motivation on the Teacher Readiness in Facing Curriculum Change at SMK 17 Magelang, SMK Bhakti Karya, and SMK Muhammadiyah Magelang. Organizational Culture can not moderate Visionary Leadership Style effect to the Teacher Readiness in Facing Curriculum Changes it shown by the equation $\mathrm{Y}=-12.284+1.128 \mathrm{X}_{1}$ $+1.123 \mathrm{Z}-0.012 \mathrm{X}_{1} * \mathrm{Z}$ and the significance value more than $5 \%(0.653$ $>0.050)$. While the Organizational Culture can not moderate Work Motivation effect to the Teachers Readiness in Facing Curriculum Changes it shown by the equation $\mathrm{Y}=$ $36.197+1.559 \mathrm{X}_{2}+1.937 \mathrm{Z}-$ $0.028 \mathrm{X}_{2} * \mathrm{Z}$ and the significance value more than $5 \%(0.163>0.050)$.

\section{Suggestions}

1. Accounting Teachers

Based on the data, the lowest score answered by respondent seen on the items and statment statement "I find a way to solved the difficulties I face". Those poin indicated low motivation in performing their work and low motivation in facing curiculum change. 
Therefore, accounting teachers are expected to increase their work performance and their Readiness in Facing Curiculum Changes in the future. To increase their work performance, teachers can find the solution by finding the information related to the suitable method that can be applied in the class, training for teachers, and find the information about how to applied new curiculum nowdays.

\section{Principals}

Based on the data of Visionary Leadership Style in Facing Curiculum Changes the lowest score shown on the items "The principal was less open minded to receive any suggestion from teachers against the difficulties in the curriculum implementation". The scores indicated the lack of openness in giving and accepting the suggestion for future progression. The principal expected to in increase their Vissionary Leadership Style to push the teacher facing and accept the curiculum change, by revise the vision and work together with teachers and open in any idea and suggestion so the accounting teachers will ready in facing the changes in currriculum.

3. Institutional Education

The needs in adding the training for three school located in magelang. espesialy training related to the curriculum applied. by doing the training the teacher expected to understand how to apply the curriculum in class.

4. Next Researchers

a. The next research will be better if increase their population and not only limited for accounting teacher in three school located in Magelang, but also another school in Magelang or other regions. So, the results of the research can be use to explain other schools condition.

b. The research will be more accurate if it is completed by interview or another method of research, so the validation of reasearch will be accurate and match with the reality.

c. This research cannot show that Organizational Culture is a variable that moderate the style of Visionary Leadership and Work Motivation on the Teachers Readiness in Facing Curiculum Changes. Hopefully the next research will develope another variable to complete this research limitation.

\section{REFERENCES}

Ames, C. (1984). System of Student and Teacher Motivation: Toward a Qualitative Devinition. Journal of Educational Psychology, 75 (4), 535-536.

Arikunto, Suharsimi. (2002). Metodologi Penelitian. Jakarta: Penerbit PT. Rineka Cipta.

Augusty Ferdinand. (2006). Metode Penelitian Manajemen. Semarang: Badan Penerbit Universitas Diponegoro.

Hersey \& Blanchard. (2004). Management of Organizational Behavior: Utilizing Human Resources. Prentice Hall: New Jersey.

Imam Ghozali. (2006). Aplikasi Analisis Multivariate dengan Program SPSS. Semarang: Badan Penerbit Universitas Diponegoro.

Kahan, S. (2002). Getting Change Right: How Leaders Transform Organizations from the InsideOut.PA: Performance Development Group.

Sabri Alisuf, M. (1996). Psikologi Pendidikan Berdasarkan Kurikulum Nasional.Jakarta: Pedoman Ilmu Jaya. Hal 85. 
Mulyasa, E. (2003). Kurikulum Berbasis Kompetensi: Konsep, Karakteristik, dan Implementasi. Bandung: PT Remaja Rosdakarya Qomari

Steers, R, M., \& Porter, L. W. (1983). Motivation and Work Behavior. New York, NY: McGraw-Hill.

Stephen Stolp. (1994). Leadership for School Culture. ERIC Digest, Number 91

Sugiyono. (2012). Memahami Penelitian Kualitatif. Bandung: ALFABETA.

Zulnaidi. (2007). Metode Penelitian. Medan, Sumatera Utara: Departemen Sastra Jepang Fakultas Sastra Universitas Sumatera Utara. 